\title{
Exploring sustainability potentials in vineyards through LCA? Evidence from farming practices in South Africa
}

\author{
V. Russo ${ }^{1,2} \cdot$ A. E. Strever ${ }^{3} \cdot$ H. J. Ponstein ${ }^{4,5}$
}

Received: 20 July 2020 / Accepted: 11 April 2021 / Published online: 28 April 2021

(c) The Author(s) 2021

\begin{abstract}
Purpose Following the urgency to curb environmental impacts across all sectors globally, this is the first life cycle assessment of different wine grape farming practices suitable for commercial conventional production in South Africa, aiming at better understanding the potentials to reduce adverse effects on the environment and on human health.

Methods An attributional life cycle assessment was conducted on eight different scenarios that reduce the inputs of herbicides and insecticides compared against a business as usual (BAU) scenario. We assess several impact categories based on $\mathrm{ReCiPe}$, namely global warming potential, terrestrial acidification, freshwater eutrophication, terrestrial toxicity, freshwater toxicity, marine toxicity, human carcinogenic toxicity and human non-carcinogenic toxicity, human health and ecosystems. A water footprint assessment based on the AWARE method accounts for potential impacts within the watershed.

Results and discussion Results show that in our impact assessment, more sustainable farming practices do not always outperform the BAU scenario, which relies on synthetic fertiliser and agrochemicals. As a main trend, most of the impact categories were dominated by energy requirements of wine grape production in an irrigated vineyard, namely the usage of electricity for irrigation pumps and diesel for agricultural machinery. The most favourable scenario across the impact categories provided a low diesel usage, strongly reduced herbicides and the absence of insecticides as it applied cover crops and an integrated pest management. Pesticides and heavy metals contained in agrochemicals are the main contributors to emissions to soil that affected the toxicity categories and impose a risk on human health, which is particularly relevant for the manual labour-intensive South African wine sector. However, we suggest that impacts of agrochemicals on human health and the environment are undervalued in the assessment. The 70\% reduction of toxic agrochemicals such as Glyphosate and Paraquat and the $100 \%$ reduction of Chlorpyriphos in vineyards hardly affected the model results for human and ecotoxicity. Our concerns are magnified by the fact that manual labour plays a substantial role in South African vineyards, increasing the exposure of humans to these toxic chemicals at their workplace.

Conclusions A more sustainable wine grape production is possible when shifting to integrated grape production practices that reduce the inputs of agrochemicals. Further, improved water and related electricity management through drip irrigation, deficit irrigation and photovoltaic-powered irrigation is recommendable, relieving stress on local water bodies, enhancing drought-preparedness planning and curbing $\mathrm{CO}_{2}$ emissions embodied in products.
\end{abstract}

Keywords Life cycle assessment $\cdot$ Wine grapes $\cdot$ South Africa $\cdot$ Water footprint $\cdot$ Carbon footprint $\cdot$ Irrigation $\cdot$ Scenario analysis

Communicated by Sarah Jane McLaren.

H. J. Ponstein

ponstein@dine-heilbronn.de

1 Sustainability, Economics and Waste Research Group, CSIR: Smart Places Cluster, Pretoria, South Africa

2 Environmental \& Process System Engineering, Department of Chemical Engineering, University of Cape Town, Cape Town, South Africa
3 Department of Viticulture and Oenology, Faculty of AgriSciences, Stellenbosch University, Stellenbosch, South Africa

4 Department of Economics and Management, University of Helsinki, P.O. Box 27, 00014 Helsinki, Finland

5 Deutsches Institut Für Nachhaltige Entwicklung (DINE), Max-Planck-Str. 39, 74081 Heilbronn, Germany 


\section{Introduction and background}

Over the last two decades, we have witnessed a shift within companies, governments and global organisations to examine the environmental impact of products and services across the economy. This is particularly the case for primary industries such as agriculture in the light of increasingly constrained land and water resources along with decreasing biodiversity. International markets, specifically the European Union (EU), are systematically applying pressure on imported products with, but not limited to, a high carbon footprint through potential trade barriers and border tariffs. This has resulted in environmental product declarations (EPDs) and delivery agreements, whereby suppliers are required to demonstrate their environmental sustainability (Peters and Hertwich 2007). Procurement strategies aligned with environmental purchasing (EP) are gaining traction at retailer level, pressured by consumer expectations (e.g. Ramanathan et al. 2014). Meanwhile, the economically increasingly influential cohort of Millennials perceives global warming as a problem and largely values environmentally-friendly wines (Gallenti et al. 2019). In addition, social standards in global supply chains expected by export destinations, particularly the European Union and USA, have shaped the South African wine industry. In 2010, the demand for ethically sourced products resulted in the domestic social audit scheme WIETA, which aims at assuring safe working conditions, minimum wages, the absence of forced labour and child labour and the overall respect of farm worker's rights (WIETA 2019). An event in 2016 saw South African workers in the wine sector fighting for their rights and coupled with the release of the documentary Bitter Grapes (2019), which shed light on the working conditions of farm workers at several vineyards in South Africa, and more in general in the Global South. As a consequence, South African wines were removed from supermarket shelves in Nordic countries. This highlights the role of labour and the state in the governance of global production networks (Hastings 2019). Thus, future trade barriers could be based on the ban of particularly harmful substances in global supply chains imposed by importing countries or organisations. For instance, the highly toxic herbicide Paraquat, used frequently in South African agriculture, is banned in domestic production in the USA and the EU, while it is banned throughout the global value chain in Fairtrade products (Fairtrade International no date). As an exporting country, South Africa is and will be impacted by these trends due to their role in global value chains (Pineo 2015) and environmental and social impact assessments of domestic products are gaining momentum. A literature review by Harding et al. (2020) of LCAs of South African products or sectors pictures a newly emerging field of research. Eight studies concerned the agriculture sector (dairy, livestock and crop products and processes), seven studies encompassed the energy industry (including biofuel and biogas production), and three studies concerned the mining sector (Platinum Group Metals and sandstone). LCAs were also performed for the value chains of certain textile products such as t-shirts and towels, whereas other studies were conducted for the infrastructure, water and packaging sectors (ibid.).

\subsection{Literature}

Wine production has attracted attention given potentially harmful effects on the natural environment (Christ and Burrit 2013). A growing body of literature aims at providing transparency thereof across several environmental impact categories, detailed by Ferrara and De Feo (2018). The authors identify the most common environmental impact categories included in previous literature, namely carbon footprint (CF), abiotic depletion (AD), acidification potential (AP) and eutrophication potential (EP). The last three impact categories are particularly relevant for the grape production phase (ibid.). Furthermore, environmental impacts from wine production have been examined for several leading wine-growing areas of the world, such as France (Jradi et al. 2018), Germany (Ponstein et al. 2019a), Italy (e.g. Bosco et al. 2011; Benedetto 2013; Marras et al. 2015), Portugal (Neto et al. 2013), Spain (e.g. Gazulla et al. 2010; Vázquez-Rowe et al. 2012; Villanueva-Rey et al. 2014; Meneses et al. 2016), the USA (Steenwerth et al. 2015) and Canada (Point et al. 2012). A detailed list of system boundaries and environmental impact categories of the studies mentioned above is presented by Ponstein et al. (2019b). Publications focussing on the carbon footprint from an importing country's perspective include Amienyo et al. (2014), who analysed wine produced in Australia and consumed in England, and Ponstein et al. (2019b), who assessed the global Finnish wine supply chain.

A generally high level of variability amongst results found in previous research merits highlighting. Sources range from a lack of congruency in system boundaries (Rugani et al. 2013), natural variability (Björklund 2002) of system inputs and outputs of wine production within (Steenwerth et al. 2015; Ponstein et al. 2019a) and beyond the borders of wine-growing nations (Vásquez-Rowe et al. 2013; Ponstein et al. 2019b). Natural variation in wine grape yields across harvest years (Vázquez-Rowe et al. 2012), vineyards (Ponstein et al. 2019a) and grape cultivars (Sinisterra-Solis et al. 2020) are key drivers of variability of environmental effects in wine grape production since the grape yield is the allocation factor for environmental impacts arising during the viticultural phase to the finished product (ibid.). 
In the recent years, a more granular assessment of different viticultural management routes has emerged. Point et al. (2012) included a change from conventional to organic viticulture as part of their uncertainty analysis, highlighting the importance of removing wood preservative chemicals on vineyard posts. Notably, the authors point out that exchanging synthetic fertiliser for organic fertiliser sources does not negate GHG emissions from this source, as organic fertilisers also cause emissions of ammonia, nitric oxide and nitrous oxide (ibid). Different wine grape-farming practices were analysed by Villanueva-Rey et al. (2014), who explored the environmental impacts of three vineyards in Spain which were managed biodynamically, conventionally and biodynamically while lacking certification. The conventional vineyard received organic fertiliser only, while the other two vineyards were not fertilised at all and the two biodynamically managed vineyards were managed with a very high degree of manual labour, reducing the transferability of the results to conventional viticulture. Beauchet et al. (2019) analysed the variability of environmental performance of various conventional and organic pest management options found in French vineyards, highlighting substantial interannual variations attributable to climatic conditions. Notably, organic phytosanitation practices were more susceptible to unfavourable weather conditions resulting in a decreased environmental performance than conventional viticulture practices (ibid.). Lamastra et al. (2016) assessed the sustainability of viticulture management options at farm scale by their indicator system "Vigneto" which adopts the concept of LCA for a multidimensional environmental decision support system for Italian viticulturists. Villanueva-Rey et al. (2019) explored the spatial differentiation of terrestrial ecotoxicity for copper used in the pest management of vineyards related to soil types and soil properties, including organic carbon. The authors point out methodological shortcomings of current methods for the assessment of toxicity in LCA, highlighting the need to tailor the assessment of potential toxicity to local conditions. In their comprehensive LCA of eight different viticultural practices, Sinisterra-Solis et al. (2020) assessed management options, concluding that higher yielding grape cultivars and organic practices provided a better environmental performance.

\subsection{South African wine production}

The South African wine industry has a rich history dating back to the arrival of the Dutch settlers in the Cape in 1652, followed by the French Huguenots, who brought changes in vinicultural practices and wine quality. The industry has done well since the advent of democracy in 1994, with wine exports growing significantly (Vink et al. 2012). Current production amounted to about 420 million litres of exports in 2018 and total industry wine production reached 9.6
Million hectolitres (SAWIS 2018). Wine exports represent just more than $50 \%$ of total wine sales, reflecting significant brandy and fortified wine sectors of the South African industry, with bulk wine exports amounting to about $60 \%$. At $8.6 \%$ of total agricultural product exports, wine is only surpassed by the citrus (dried and fresh) fruit industry (DAFF 2019). Imports are negligible, reflecting high tariff protection (Vink et al. 2012). Currently, South Africa is the world's 9th largest wine producer, preceded by Germany (10.3 Million hectolitres) and followed by China (9.1 Million hectolitres) (OIV 2019). The winegrowing areas in South Africa are concentrated in the South Western, North and Eastern regions (Fig. 1) with the largest producing region being located in the Western Cape Province accounting for $\sim 95 \%$ of total production (SAWIS 2018).

There is a strong geographic overlap with one of the world's most renowned biodiversity hotspots, the Cape Floral Kingdom. Less than $7 \%$ are rain-fed vineyards, with most of the production being irrigated (Personal Communication, Christo Spies, WineMS, Paarl). The grape yield per hectare expands from 6 to 8 tons for non-irrigated vineyards, to as much as 18-21 tons for irrigated highproduction vineyards. Apart from the irrigation regime, factors such as the cultivar, the age of the vineyard and quality aspirations are decisive factors for yields. The usual farming practices for commercial wine grape production encompassed chemical weed management and the use of insecticides. However, this practice is facing growing limitations from an increase in resistances against the active ingredients used for weed and pest control while entailing environmental and health risks. Coping with these limitations by increasing the frequency of application of herbicides and insecticides and in the concentration of the active ingredient per application, as well as by a cocktail of active ingredients magnifies production cost, environmental pollution and health risks.

\section{Material and methods}

\subsection{Goal and scope}

This is the first LCA on nine different wine grape-farming practices which are all suitable for commercial conventional production in South Africa. Following the impetus to curb environmental impacts across all sectors globally and given the lack of LCA studies addressing wine production in South Africa, this paper contributes to the transparency of environmental effects from this crucial export industry. In accordance with Frischknecht and Stucki (2010), we applied the attributional LCA approach to the single scenarios based on the 'economic size criterion' of the South African wine sector. Investigating 


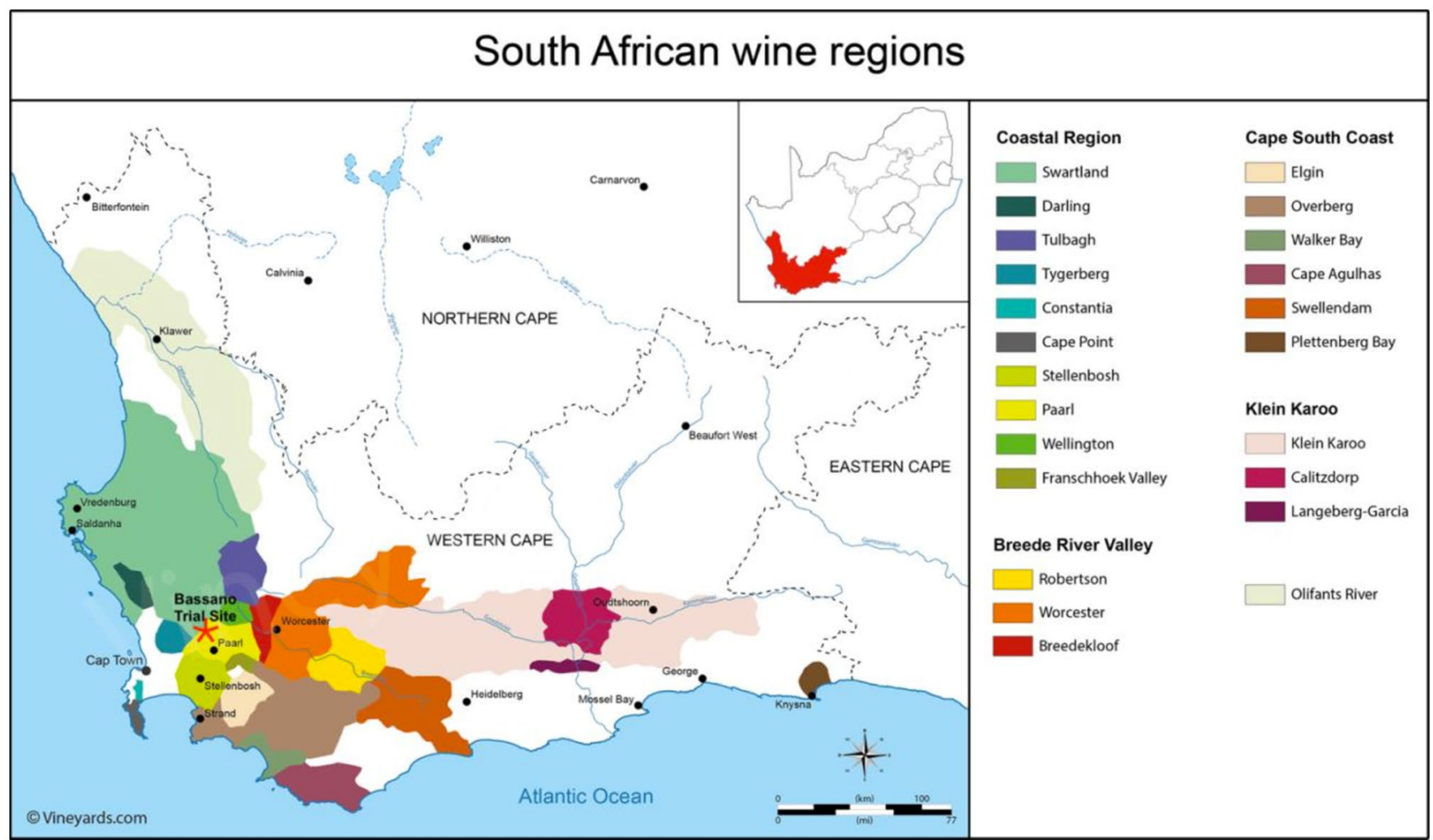

Fig. 1 Wine-growing regions in South Africa ( source: vineyards.com, modified)

alternative approaches to common viticulture practices, this study aims at understanding the feasibility and effects of cover crops for weed control compared to full-surface herbicide treatment and of replacing insecticides by natural pest control. Supported by data from an on-farm trial, eight scenarios are compared against the business as usual (BAU) practice. We assess several ReCiPe 2016 Midpoint $(\mathrm{H})$ impact categories, namely global warming potential, terrestrial acidification, freshwater eutrophication, terrestrial toxicity, freshwater toxicity, marine toxicity, human carcinogenic toxicity and human non-carcinogenic toxicity. In addition, two damage assessment categories, namely Human health and ecosystems, from ReCiPe 2016 Endpoint $(\mathrm{H})$ were included to account for toxicity impacts on human beings and the environment at end point level. The functional unit is $1 \mathrm{~kg}$ of wine grapes at the farm gate.

The assessment covers the growing of wine grapes over 1 year in the Perdeberg area (Western Cape Province) in South Africa from 1st of April 2016 to 31st of March 2017, which is one complete growing season. The on-farm trial is located in a vineyard close to Wellington, South Africa, at $33^{\circ} 34^{\prime} 15.8^{\prime \prime} \mathrm{S} 18^{\circ} 53^{\prime} 34.5^{\prime \prime} \mathrm{E}$ (Fig. 1) and consists of 60 rows with 40 vines per row in a Cabernet Sauvignon vineyard of 1 ha with an average yield of 8 tons.

\subsection{Life cycle inventory and data modelling}

Eight (8) alternative management options were investigated. Scenarios 2, 4, 6 and 8 are based on a winter cover crop in every row of the vineyard. In scenarios $1,3,5$ and 7, every second row was planted with a cover crop while the alternate row received herbicide applications.

A winter cover crop provides an alternative to full-surface chemical weed management (e.g. Swanton and Weise 1991; Baumgartner et al. 2008; Fox 2000; Fourie 2010, Fourie et al. 2017), reducing the requirement for chemical weed management. Sown in autumn at the beginning of the rainy season, the cover crop competes with weeds for space, light, nutrients and water and prevents weeds from growing in the working rows (Fourie et al. 2017; Fourie 2010; Fourie et al. 2001). The main difference between the cover crop and the weeds is the time of growth: the life cycle of a winter cover crop will ideally have been completed towards the end of the rainy season and therefore its competition for water and nutrients with the vines is limited from the beginning of the phenological development of the vines onwards. Conversely, certain weeds tend to grow throughout the year, competing for water all along the phenological stages of the vine and potentially reducing yields as a consequence (ibid.). The water usage of a cover crop at vineyard level can be reduced 
by planting every second row (a common practice in South Africa), compared to every row, which may be a preferred option on particularly dry sites (Peth et al. 2017) and was trialled in scenarios 1, 3, 5 and 7.

Chemical weed control requires 2 to 3 full-surface applications in the baseline scenario, which can be reduced to an area of $30 \%$, representing the under-vine section only, since working rows are planted with a cover crop. The under-vine section was left bare and treated with herbicides in each scenario. Hence, a cover crop in each row represented a $70 \%$ reduction in herbicide usage and corresponding diesel usage, while a cover crop in every second row reduced these agricultural inputs by $35 \%$ only. On the other hand, establishing a cover crop requires tillage to prepare the soil, sowing, and in some cases fertilization. In the on-farm trial, seeding and fertilization were done in separate working steps given the available machinery. The trial varied fertiliser application. Half of the cover crop ("A") received $50 \mathrm{~kg} \mathrm{~N}$ in the form of lime ammonium nitrate per hectare, while the other half ("B") did not receive fertiliser.

The cover crop was harvested by the farmer and used as straw and fodder. While this is an interesting additional usage of the working rows of vineyards and a potential coproduct, we did not explore this option as it is beyond the scope of this paper. Notably, the yields were very low due to the low fertiliser dosage compared to grain farming. However, we encourage future research to explore the possible cross-links between cover crops grown in vineyards for the sake of soil health, weed management and animal husbandry.

The replacement of insecticides by natural enemies is a key element of an Integrated Pest Management approach (e.g. Abrol 2013). Whereas insecticides come with potentially significant health risks for the farm staff and communities close to vineyards, their complete replacement by natural enemies of the target pest is possible. In our example, the chemical control of the pest mealybug required up to three applications of Spirotetramat and one application of Chlorpyriphos every third year. The release of natural enemies that target mealybugs replaced the need for chemical pest control within the same year, making the usage of synthetic insecticides unnecessary while achieving full crop protection. Scenarios 3, 4, 7 and 8 reflect the application of natural enemies instead of synthetic insecticides.

The life cycle inventory was informed by a combination of literature, publicly available sources and primary data from the trial (Table 1). Primary data were gathered by the on-farm trial and personal communication with experts. Those were complemented or augmented by relevant literature including sector reports and mass balance calculations. Data include.

- Inputs from nature: land, water (precipitation) and energy content of biomass. Information on precipitation was gathered from the South African Weather Services (ISO 9001 compliant).

- Inputs from the technosphere: electricity and fuel usage for farming practices, water for irrigation (inclusive of infrastructure), fertilisers and pesticides and other materials (i.e. agricultural machinery for field spraying).

- Emissions: direct field emissions from fertiliser applications were calculated using Nemecek et al. (2011); specifically, emissions to air related to $\mathrm{N}$-fertiliser application were modelled as $\mathrm{NH} 3, \mathrm{~N} 2 \mathrm{O}, \mathrm{NOx}$ emissions, while acknowledging heavy metal emissions ( $\mathrm{Cd}, \mathrm{Zn}, \mathrm{Pb}, \mathrm{Ni}$, $\mathrm{Cr}, \mathrm{Hg}$ ) extending to all agricultural inputs. Emissions to water related to $\mathrm{N}$ - and $\mathrm{P}$-fertiliser application were modelled as nitrate to groundwater, phosphate to groundwater and phosphate and phosphorus to surface water. All pesticides applied for crop production were assumed to end up as emissions to the soil (ibid.).

- Water inputs for irrigation: information on irrigation were gathered from personal communication with farmers and viticulturist experts and low, average and high irrigation patterns were developed. A specific set of irrigation data was modelled by adapting the South African background irrigation datasets from the ecoinvent V. 3.6 database, available online at the time the study was conducted (Ecoinvent, n.d.) but not available in the SimaPro software (V. 8.5), to correctly represent energy usage (electricity only) for pumping at farm and the irrigation technology (drip irrigation only).

- Agrochemicals: when primary data was not available, the amounts were derived from Dabrowski et al. (2014). Given the lack of specific background data in ecoinvent V. 3.5, the 'Triazine compound' was a proxy for Terbuthylazine and the Bipyridylium compound was a proxy to model Paraquat. The 'Organophosphorus compound' was a proxy to model Chlorpyriphos, while a 'generic chemical, inorganic' was a proxy to model Spirotetramat, Penconazole and Spiroxamine.

The irrigation water application was the same for all scenarios and so was the corresponding electricity usage of the water pumps. 'Farming practices' refer to activities such as fertiliser and agrochemical application, tillage, sowing as well as vineyard maintenance (pruning). In the life cycle impact assessment, emissions from diesel usage at farm (burned in agricultural machinery) were decoupled from emissions arising from direct fertiliser and agrochemical application.

The trellis system was excluded from the LCI since impacts are mostly related to its production and the aim of this study was to assess the environmental impacts of viticulture practices. Further, human labour was excluded. Staff either live on the wine farms, requiring little or no 


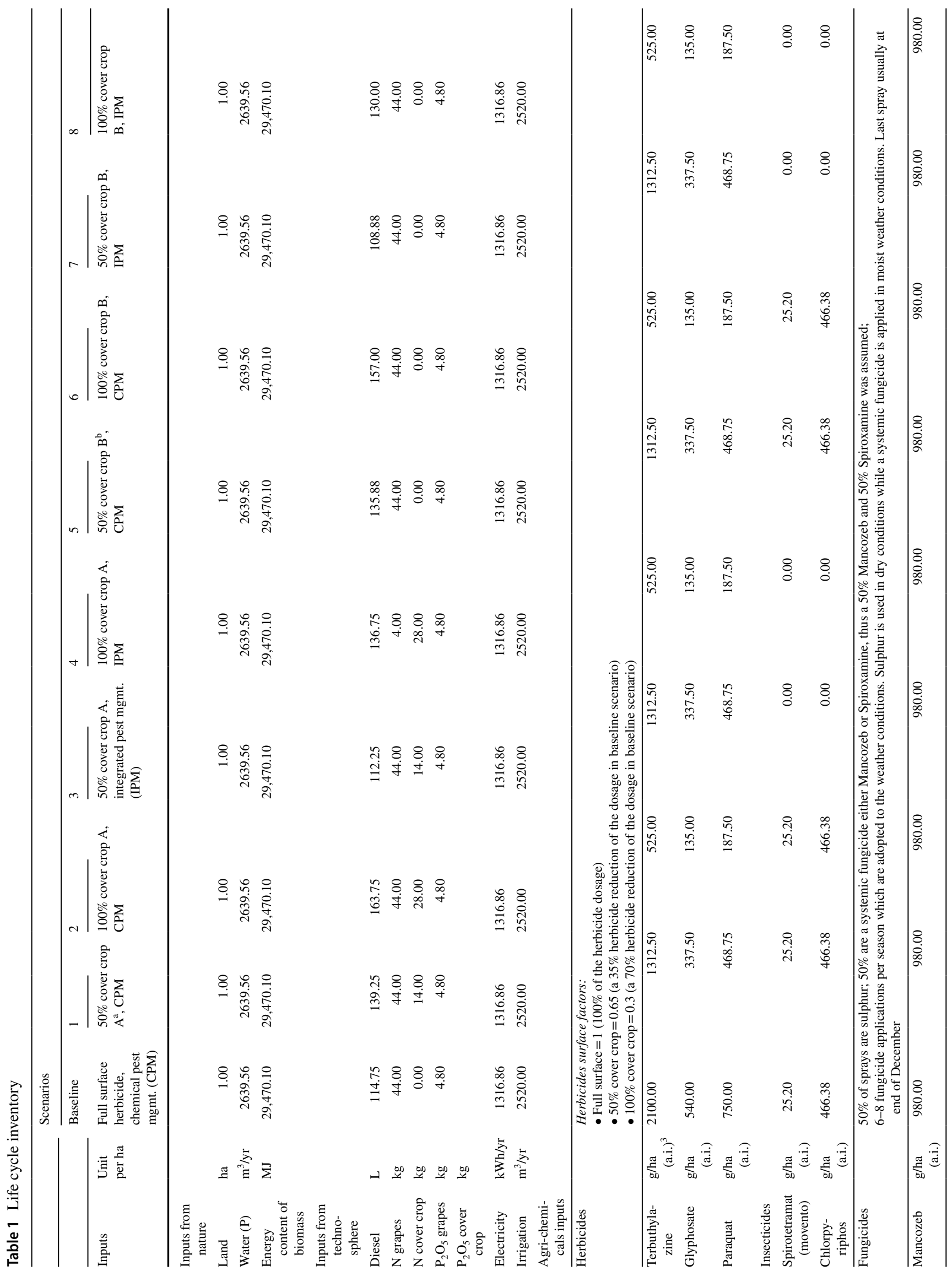




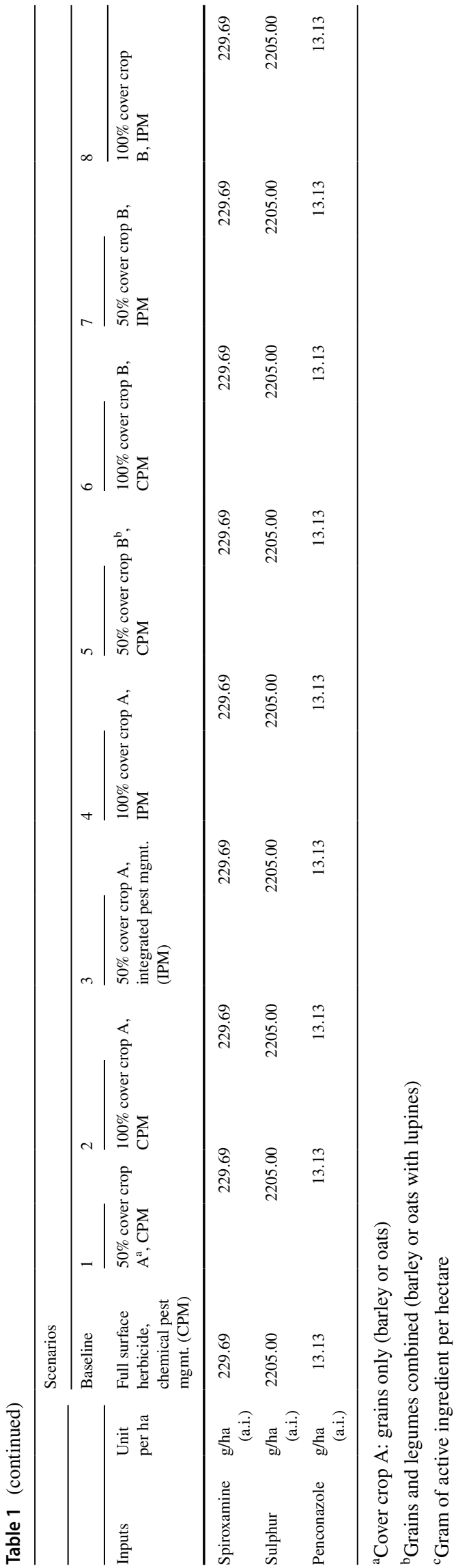

transportation to the workplace, or is sourced from adjacent villages and informal settlements. In the latter case, transport could represent an important element to the environmental impact of wine grape production, which is beyond our scope. We have assumed that staff lived on or close by the farms, requiring no transport.

\subsection{Life cycle impact assessment}

The impact assessment was conducted using the ReCiPe 2016 Midpoint(H) method (Huijbregts et al. 2016). Of the 18 mid-point impact categories available, those investigated were global warming potential, terrestrial acidification, freshwater eutrophication, terrestrial toxicity, freshwater toxicity, marine toxicity, human carcinogenic toxicity and human non-carcinogenic toxicity. Two damage assessment categories, namely human health and ecosystems, from ReCiPe 2016 Endpoint(H) (ibid.) were also included to account for toxicity impacts on human beings and environment and end point level.

The SimaPro V. 8.5 software was used to build the life cycle inventory (LCI) models and perform the life cycle impact assessments. The modelling was based on ecoinvent V. 3.5 unit datasets.

\subsection{Water footprint assessment}

Consumptive water was calculated using the ReCiPe 2016 Midpoint(H) method, while a water footprint assessment (WFA) was done separately to account for impacts on the local environment, assessing the stress faced by the water resources within the area of the trial site. ReCiPe 2016 supports the accounting of the amount of water needed but does not provide an impact assessment, which was added using the AWARE method (Boulay et al. 2018). A water footprint is a measure of how much water a process or service requires and the resulting direct and indirect environmental impacts, measuring local water scarcity, typically expressed volumetrically. This number can be interpreted as the amount of water downstream users are lacking as a function of water consumption on site and thus, the WFA depicts the pressure exerted by an activity (wine grape farming in our case) on the watershed area. The AWARE method illustrates the use-to-resource ratio, namely demand-to-availability, and indicates the relative impact on downstream water users compared to the average water consumption in the world. Thereby, we assess the relative Available WAter REmaining per area in a specific watershed after the demand of humans and aquatic ecosystems has been met (Boulay et al. 2018) and apply a local and national characterization factor (Table 2).

The main challenge in a WFA is to get the most representative data for the specific local conditions. Global data 
is generally more readily available to cover background processes to the life cycle; however, the relevance of the results based on global data may be lower compared to local data, since the latter are more relevant to and representative of the local situation. Local input data on irrigation water were retrieved from personal communication with local experts, whereas water inputs attributable to precipitation were calculated using rainfall data gathered from the South African Weather Services (no date) and two local weather stations (Perdeberg and Nooitgedacht). Water used in upstream ancillary processes was calculated based on ecoinvent.

\subsection{Sensitivity analysis}

Electricity from irrigation has a high contribution to most of the impact categories and was not modified throughout the scenarios. To test the responsiveness of the result to changes in the electricity requirement or irrigation water requirement, we included this sensitivity analysis at the example of the GWP results using the ReCiPe 2016 Midpoint(H) method. Electricity and irrigation inputs are interlinked since energy is required for the water pumps. Therefore, a variation of one affects the other, and this sensitivity analysis is helpful in understanding the environmental effects under several possible energy and water usage options.

With regard to the electricity inputs, there is a large variation between the peak, standard and off-peak tariff as well as the prices between the high and low seasonal demand (Eskom 2017). We considered five different electricity inputs based on background data (ecoinvent V 3.5 database) and secondary data (Eskom) and their effect on the GWP per $\mathrm{kg}$ wine grapes (Table 3). The ecoinvent background dataset assumes irrigation via a combination of drip, sprinkler and surface irrigation as well as a combination of electricity sources from the national grid and diesel-powered generators. This was adapted to represent the irrigation pattern of our trial, which was drip irrigation and grid electricity input only. Here, the irrigation water input was kept constant at the value of $2520 \mathrm{~m}^{3} / \mathrm{ha} /$ year across the scenarios as per Table 1 .

Concerning the sensitivity analysis of irrigation water inputs, we explored low, average and high irrigation schemes, which relate to seasonal rainfall variation and public water availability, both strongly reduced in drought years.
South Africa experienced 3 years of extreme drought from 2016 until 2018, which affected standard irrigation practices. Thus, a low-irrigation scheme is likely to be implemented during droughts (Table 4). The electricity requirement of the baseline scenario (Table 1) was modified linearly according to the decreased or increased irrigation water to be pumped for a low or high irrigation scheme.

\section{Results}

As a main trend, most of the impact categories were dominated by energy requirements of wine grape production of an irrigated vineyard, hence the usage of electricity and diesel. Strong modifications in the usage of agrochemicals did not lead to corresponding changes in the results concerning the ReCiPe mid-point impact categories global warming potential, terrestrial acidification, human carcinogenic and non-carcinogenic toxicity as well as the for end-point damage categories human health and ecosystems. The most favourable scenario across the impact categories was scenario 7 (50\% cover crop B and integrated pest management) due to low diesel usage, reduced herbicides and the absence of insecticides, whereas scenario $2(100 \%$ cover crop A and chemical pest management) showed the highest environmental impacts attributable to high amounts of diesel inputs, fertiliser and the use of insecticides of all analysed options. In general, scenarios which included the integrated pest management-namely, 3, 4 and 8-scored better than those relying on agrochemicals only and differences can be attributed to the choice of the fertiliser regime. Further, the results show a rather high sensitivity of the model towards changes in diesel usage compared to changes in the agrochemicals. The contribution analysis for each specific category revealed the following: the main contributors to emissions to soil that affect the toxicity categories were heavy metals in fertiliser and pesticides, particularly the pesticide Chlorpyrifos and the fungicide Mancozeb. $\mathrm{CO}_{2}$ emissions from coal-fired power plants contribute largely to global warming potential, while $\mathrm{SO}_{2}$ and NOx from the same source are the main drivers for terrestrial acidification. Freshwater eutrophication origins mainly from P-fertiliser application at farm and mining waste spoils related to the coal-fired electricity production.
Table 2 WFA based on the AWARE method for $1 \mathrm{~kg}$ wine grapes

\begin{tabular}{llll}
\hline Water source & $\begin{array}{l}\text { Water usage } \\
\left(\mathrm{m}^{3} / \mathrm{kg}\right)\end{array}$ & $\begin{array}{l}\text { Impact assessment at the } \\
\text { country level }\left(\mathrm{m}^{3}-\mathrm{eq} / \mathrm{kg}\right)\end{array}$ & $\begin{array}{l}\text { Impact assessment at the } \\
\text { local watershed level }\left(\mathrm{m}^{3} \text {-eq/ }\right. \\
\mathrm{kg})\end{array}$ \\
\hline Total blue water & 0.317 & 12.91 & 19.38 \\
Irrigation & 0.315 & 12.83 & 19.26 \\
$\begin{array}{l}\text { Ancillary processes } \\
\begin{array}{l}\text { Total green water from } \\
\text { precipitation }\end{array}\end{array}$ & 0.002 & 0.08 & 0.12 \\
\hline
\end{tabular}


Table 3 Sensitivity analysis of electricity inputs and related GWP

\begin{tabular}{|c|c|c|c|c|}
\hline $\begin{array}{l}\text { Scenario (all diesel and electricity inputs are } \\
\text { for pumping) }\end{array}$ & $\begin{array}{l}\text { Electricity input (MJ } \\
\text { to pump } 1 \mathrm{~m}^{3} \text { of } \\
\text { water) }\end{array}$ & $\begin{array}{l}\text { Overall GWP (kg } \\
\mathrm{CO}_{2} \text {-eq/kg wine } \\
\text { grapes) }\end{array}$ & $\begin{array}{l}\text { Irrigation contribution } \\
\text { (kg CO} 2 \text {-eq/kg wine } \\
\text { grapes) }\end{array}$ & $\begin{array}{l}\text { Irrigation contribution } \\
\% \text { of the total GWP }\end{array}$ \\
\hline Background dataset ${ }^{\mathrm{a}}$, no adaptation & $\begin{array}{l}\mathrm{D}^{\mathrm{b}}: 0.252 \\
\mathrm{E}^{\mathrm{c}}: 0.441\end{array}$ & 0.259 & 0.053 & $20.6 \%$ \\
\hline $\begin{array}{l}100 \% \text { drip irrigation and background die- } \\
\text { sel + electricity }\end{array}$ & $\begin{array}{l}\text { D: } 0.252 \\
\text { E: } 0.441\end{array}$ & 0.284 & 0.079 & $27.6 \%$ \\
\hline $\begin{array}{l}100 \% \text { drip irrigation and background electric- } \\
\text { ity }\end{array}$ & $\begin{array}{l}\text { E: } 0.691 \\
\text { D: } 0.000\end{array}$ & 0.303 & 0.097 & $32.0 \%$ \\
\hline $\begin{array}{l}100 \% \text { drip irrigation and (Eskom) average } \\
\text { tariff electricity (used in our analyses) }\end{array}$ & $\begin{array}{l}\text { E: } 1.967 \\
\text { D: } 0.000\end{array}$ & 0.435 & 0.229 & $52.6 \%$ \\
\hline $\begin{array}{l}\text { 100\% drip irrigation and (Eskom) standard } \\
\text { tariff electricity }\end{array}$ & $\begin{array}{l}\text { E: } 2.245 \\
\text { D: } 0.000\end{array}$ & 0.464 & 0.258 & $55.7 \%$ \\
\hline
\end{tabular}

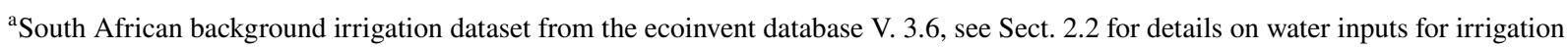

${ }^{\mathrm{b}} \mathrm{D}$ : Diesel generator-based electricity

${ }^{\mathrm{c}} \mathrm{E}$ : Grid electricity

The following subsections provide further details on processes and substance contributions to each impact category. Figure 2 illustrates the contribution analysis comparison for each one of the impact categories investigated and the respective process contributions at midpoint level. Figure 3 and 4 show the contribution analysis comparison for the endpoint damage categories human health and ecosystems.

\subsection{Global warming potential}

Irrigation inclusive of electricity contribution is mostly the same for all the scenarios and it accounts for $\sim 50 \%$ on average. Diesel usage accounts for an $24.2 \%$ on average of the total global warming potential (GWP) across all the scenarios (ranging from 20.5 to $28.2 \%$ ). Fertilisers and agrichemical production account for a $\sim 17 \%$ on average (ranging from 15 to $22 \%$ ) and this is due to the different usage amounts across the scenarios. Farming practices inclusive of fertilisers and agrochemical emission contributions account for an average $8.3 \%$ on the total global warming potential (GWP) across all the scenarios (ranging from 7.6 to $10.2 \%$ ). Substances that contribute to GWP emissions are mainly fossil $\mathrm{CO}_{2}$ which accounts for $75.4 \% ; \mathrm{N}_{2} \mathrm{O}$ which accounts for about $17 \%$; fossil $\mathrm{CH}_{4}$ which accounts for a $6.2 \%$.

\subsection{Terrestrial acidification}

Irrigation inclusive of electricity is the major contributor to the terrestrial acidification (TA) $(\sim 60 \%$ of total impacts on average) due to the fact that electricity for irrigation is mainly coal-fired and $\mathrm{SO}_{2}$ and $\mathrm{NOx}$ are generated from the burning of coal. This is followed by diesel usage (18.6\% of total impacts on average) due to the fact that one third of South African diesel is produced from coal via the FisherTropsch synthesis. Fertilisers and agrochemical production contribute to an average of $\sim 12 \%$, followed by farming practices with an average $8.2 \%$. Substances that contribute to TA emission are mainly sulphur dioxide which accounts for $67 \%$; nitrogen oxides (NOx) which accounts for about $20 \%$; ammonia $\left(\mathrm{NH}_{3}\right)$ which accounts for $13.3 \%$.

\subsection{Freshwater eutrophication}

The major contributors to freshwater eutrophication (FE) are the treatment of mining waste via landfilling and P-fertiliser application. Irrigation inclusive of electricity is the major contributor to the FE ( $\sim 62 \%$ of total impacts on average). Farming practices account for an average of $\sim 20 \%$ while diesel usage accounts for $12 \%$. Fertilisers and agrochemical

Table 4 Sensitivity analysis of irrigation water inputs and related GWP

\begin{tabular}{lllll}
\hline Scenario & $\begin{array}{l}\text { Water input }\left(\mathrm{m}^{3} \text { of water per }\right. \\
1 \text { ha per 1 year) }\end{array}$ & $\begin{array}{l}\text { Overall GWP }(\mathrm{kg} \mathrm{CO} \text {-eq/ } \\
\mathrm{kg} \text { wine grapes) }\end{array}$ & $\begin{array}{l}\text { Irrigation contribution (kg } \\
\mathrm{CO}_{2} \text {-eq/ kg wine grapes) }\end{array}$ & $\begin{array}{l}\text { Irrigation contribu- } \\
\text { tion \% of the total } \\
\mathrm{GWP}\end{array}$ \\
\hline Low irrigation & 600 & 0.267 & 0.062 & $23.1 \%$ \\
Average irrigation & 2520 & 0.435 & 0.229 & $52.6 \%$ \\
High irrigation & 3840 & 0.601 & 0.395 & $65.7 \%$ \\
\hline
\end{tabular}


production follow with an average contribution of $\sim 6 \%$. Substances that contribute to FE emission are mainly phosphate $(\sim 90 \%)$ and phosphorus ( 10\%) emissions to water.

\subsection{Terrestrial ecotoxicity}

Irrigation inclusive of electricity accounts for an average of $\sim 54 \%$, followed by diesel usage (20\%), fertilisers and agrochemical production $(\sim 20 \%)$ and farming practices (7.8\%). Chlorpyrifos accounts for almost the totality of farming practices impacts on terrestrial ecotoxicity.

\subsection{Freshwater ecotoxicity}

Irrigation inclusive of electricity accounts for an average of $\sim 54 \%$. The contribution of farming practices ranges from a minimum $4.2 \%$ in scenarios 4 and 8 due to the avoidance of Chlorpyriphos and fertiliser to a maximum of $37.4 \%$ (baseline scenario). Diesel usage and fertilisers and agrochemical production account for a 5.30 and $5.1 \%$ of total impacts on average, respectively. Freshwater ecotoxicity trace to: Chlorpyrifos and Mancozeb account for $92.7 \%$ and $6.3 \%$ of emissions to soil, respectively, to the relative $~ 38 \%$ for farming practices; heavy metal emissions-from fertilisers, pesticides and heavy metal content of plant materialwhich account for the bulk of the relative share to the overall freshwater ecotoxicity. Single contributors were as follows: irrigation inclusive of electricity (copper 68.2\%, zinc, $25.6 \%$, nickel $2.3 \%$ ), diesel usage (zinc $63.3 \%$, copper $15.2 \%$, nickel $5.8 \%$ ) and fertiliser and agrochemical production (zinc $68.5 \%$, copper $\sim 13.0 \%$, nickel $4.7 \%$ and chromium VI $1.1 \%)$.

\subsection{Marine ecotoxicity}

Irrigation inclusive of electricity accounts for an average of $\sim 75 \%$ of total impacts. The contribution of farming practices ranges from a min $0.6 \%$ (scenario 4 ) to a max of $13.0 \%$ (baseline scenario); diesel usage and fertilisers and agrochemical production account for $7.2 \%$ and $6.5 \%$ of average impacts, respectively. Substances that contribute to marine ecotoxicity are mainly Chlorpyrifos and Mancozeb emitted to soil (95.8\% and $1.1 \%$, respectively). Zinc emissions to water (3.0\%), arising mainly from irrigation inclusive of electricity with a $\sim 29 \%$ contribution to its relative share and to diesel usage with $a \sim 65 \%$ contribution to its relative share.

\subsection{Human carcinogenic toxicity}

Irrigation inclusive of electricity accounts for an average of $57.5 \%$. Diesel usage and fertilisers and agrochemical production account for a $35 \%$ and $7.3 \%$. Farming practices had a negligible $(0.04 \%)$ impact. Human carcinogenic toxicity traces to chromium VI to water arising from each of the main processes, namely irrigation inclusive of electricity, diesel usage and fertilisers and agrochemical production, accounting for $60 \%, \sim 33 \%$ and $\sim 7 \%$, respectively. Interestingly, the baseline scenario, which has the highest input of glyphosate as per Table 1, showed very low impacts which can be explained by the fact that the carcinogenic effects from glyphosate were not yet accounted for by the current version of the background data of the toxicity assessment.

\subsection{Human non-carcinogenic toxicity}

Irrigation inclusive of electricity accounts for $\sim 45 \%$ of total impacts. Diesel usage and fertilisers and agrochemical production account for an average of $41.4 \%$ and $10.7 \%$, respectively. Farming practices showed little impact (3.1\%) on average. Substances that contribute to human non-carcinogenic toxicity emissions are mainly zinc emissions to water $(60.6 \%)$ and soil $(32.5 \%)$.

\subsection{Human health}

Irrigation inclusive of electricity accounts for $\sim 51 \%$ of total impacts. Farming practices accounts for $30 \%$, diesel usage and fertilisers and agrochemical production account for $\mathrm{a} \sim 13 \%$ and $\sim 6 \%$, respectively. Substances that contribute to human health impacts are mainly given by water consumption at farm (26.3\%); dinitrogen monoxide (2.9\%) arising from farming activities inclusive of diesel, fertiliser and agrochemical production and usage and zinc emissions to soil $(2.1 \%)$ and to water $(3.8 \%)$.

\subsection{Ecosystems}

Results across all the scenario are very similar with a spread of $0.14 \%$ with farming practices accounting for an average of $\sim 95 \%$. Irrigation inclusive of electricity, diesel usage and fertilisers and agrochemical production account for a $4.2 \%$, $0.5 \%$ and $0.3 \%$, respectively. Main contributors to ecosystem damage are land occupation ( 92\%) and water usage ( 3\%), both related to farming practices.

\subsection{Water footprint assessment results}

The water usage per $1 \mathrm{~kg}$ of wine grapes produced is of about $0.646 \mathrm{~m}^{3} / \mathrm{kg}$ of wine grapes and consists of irrigation water $\left(0.315 \mathrm{~m}^{3} / \mathrm{kg}\right)$ measured on the farm, upstream ancillary processes not directly at farm level $\left(0.002 \mathrm{~m}^{3} / \mathrm{kg}\right)$ and green water from precipitation $\left(0.329 \mathrm{~m}^{3} / \mathrm{kg}\right)$ according to $\mathrm{ReCiPe} 2016 \mathrm{Midpoint}(\mathrm{H})$. The amount of irrigation water corresponds to the average irrigation scenario as per Table $1\left(2520.00 \mathrm{~m}^{3} / \mathrm{ha} /\right.$ year $)$ for all scenarios presented in this article. The amount of abstracted water used at farm for 

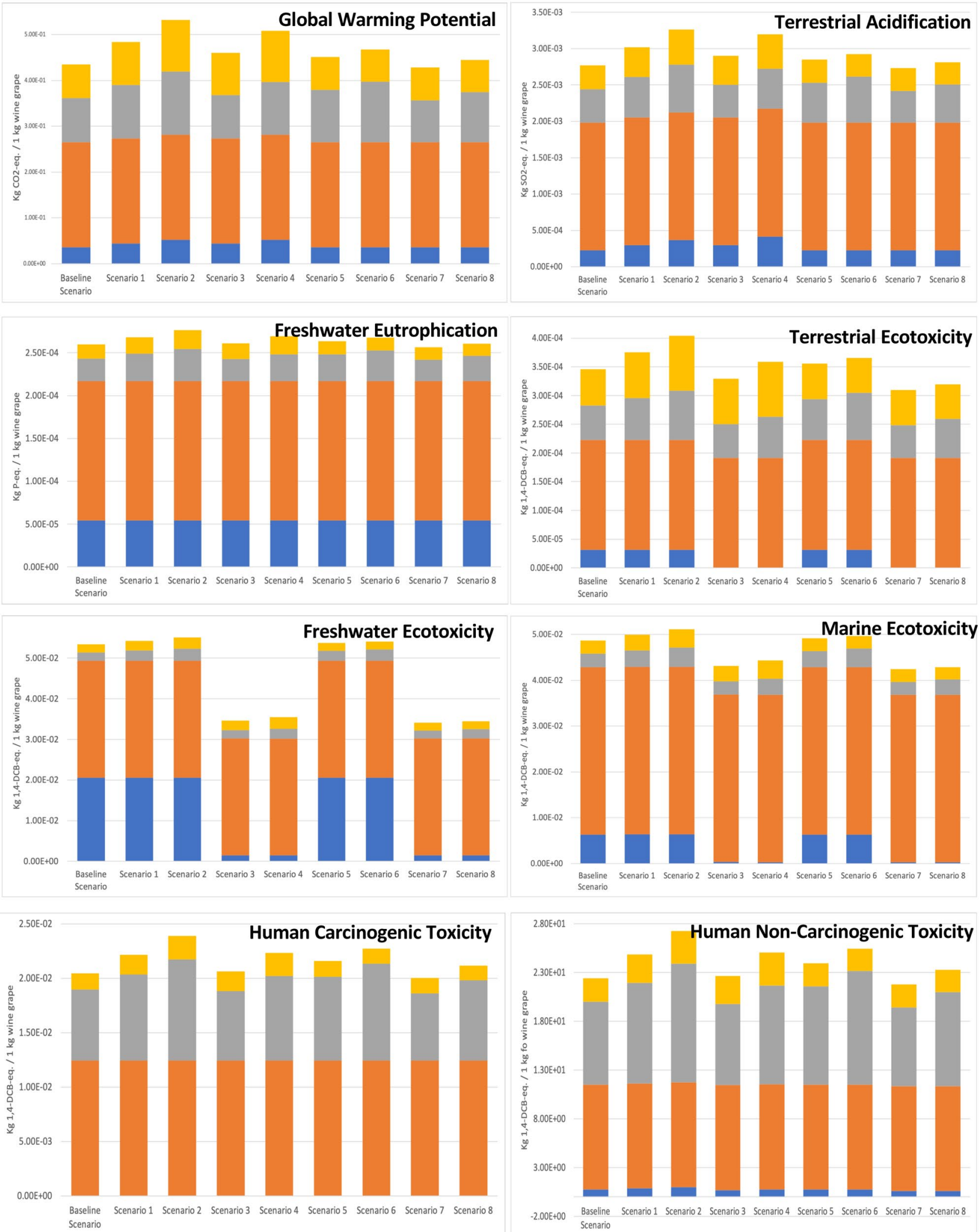

- Farming practices inclusive of fert\&agro-chemicals application I Irrigation inclusive of electricity Diesel Usage a Fert+agro-chemical production

Fig. 2 LCIA results comparison. Global warming potential, terrestrial acidification, freshwater eutrophication, terrestrial ecotoxicity, freshwater ecotoxicity, marine ecotoxicity, human carcinogenic toxicity and human non-carcinogenic toxicity 


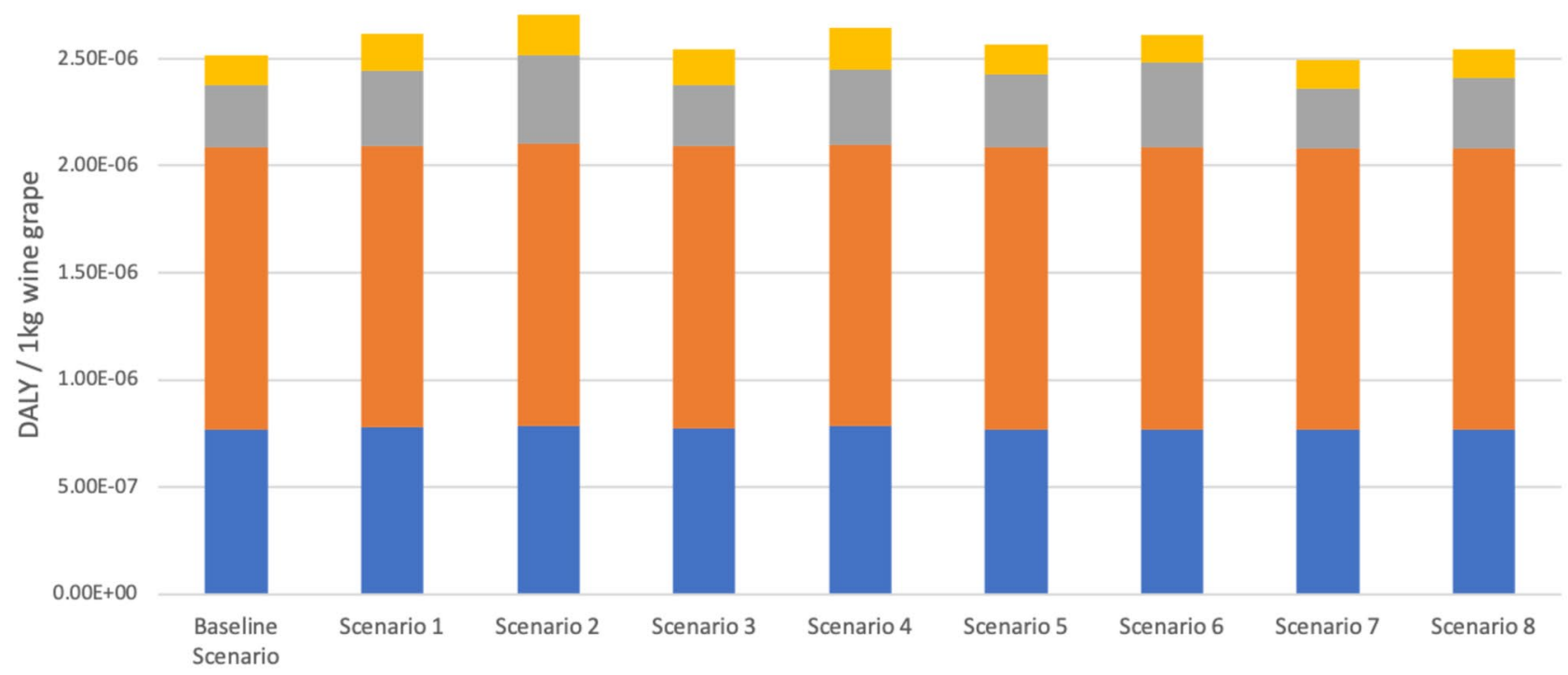

- Farming practices inclusive of fert\&agro-chemicals application a Irrigation inclusive of electricity $\quad$ Diesel Usage $\|$ Fert+agro-chemical production

Fig. 3 Human health damage assessment contribution results

irrigation is $0.315 \mathrm{~m}^{3} / 1 \mathrm{~kg}$ wine grape represents the irrigation pattern of our trial and is based on the following expert information:

- $2 \mathrm{~mm}$ water per hour;

- $12 \mathrm{~h}$ per week;

- 10 weeks of irrigation until harvesting, the low to high irrigation scenario range is $5-16$ weeks.
Applying the local AWARE indicator of $61.2 \mathrm{~m}^{3}-\mathrm{eq} / \mathrm{m}^{3}$ to the irrigation water abstracted by the farm in the watershed of the Perdeberg area, the result is $19.38 \mathrm{~m}^{3}$-eq per $\mathrm{kg}$ wine grapes. This is a moderate result stating that the water usage of $0.317 \mathrm{~m}^{3}$ per $\mathrm{kg}$ grapes in this area relates to a water deficit of $\sim 19 \mathrm{~m}^{3}$-eq for human activities and the ecosystem. As a reference, the world average is $1 \mathrm{~m}^{3}-\mathrm{eq} / \mathrm{m}^{3}$. Therefore, wine production in this region clearly exacerbates the competition for

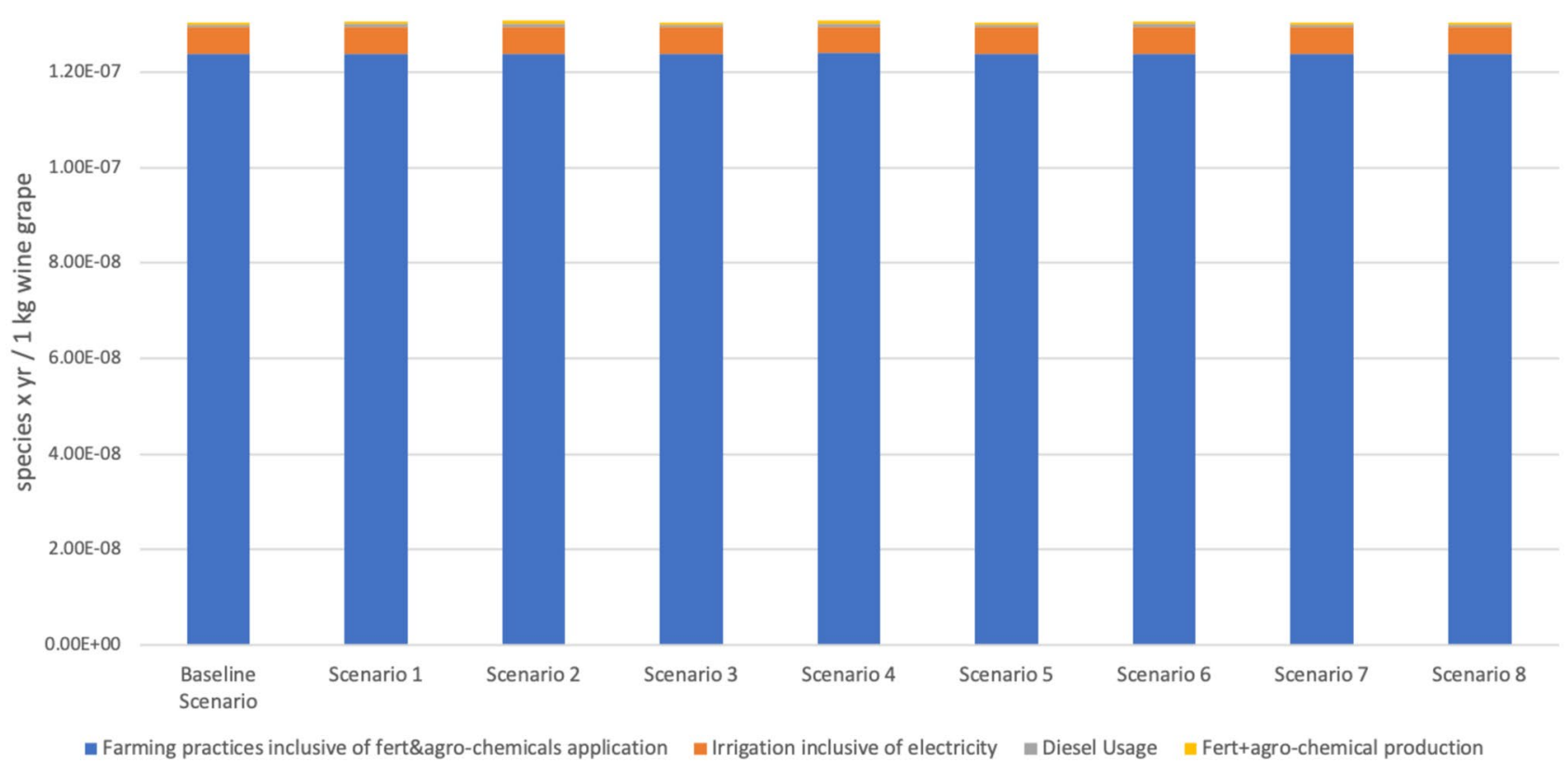

Fig. 4 Ecosystem damage assessment contribution results 
already scarce water resources, also compared to other regions within the country. Applying the AWARE indicator for South Africa at country level $\left(40.76 \mathrm{~m}^{3}-\mathrm{eq} / \mathrm{m}^{3}\right)$ results in only 12.83 $\mathrm{m}^{3}-\mathrm{eq} / \mathrm{kg}$, which is clearly lower than the results on the watershed level, underscoring the need to rely on the most representative data and highlighting that the wine grape production is located in a particularly water-scarce region of the country. Table 2 reports the consumptive water quantity and the water footprint assessment results for the AWARE method, including the different AWARE Characterisation Factors for South Africa at the country level and at the watershed level for the trial site, allowing for a comparison between national and regional scales.

\subsection{Sensitivity analysis on key parameters}

Results in Table 3 cover the sensitivity analysis of electricity inputs, showing the energy inputs consisting of grid electricity (E) and electricity from a diesel-powered generator (D) and resulting greenhouse gas emissions for five possible variations of energy usage for irrigation. According to this sensitivity analysis, the contribution of energy inputs for irrigation to the GWP of wine grapes can increase from $21 \%$ when applying the background dataset, no adaptation to as much as $56 \%$ according to $100 \%$ drip irrigation and Eskom standard electricity tariff.

Our findings in Table 4 concern the variations in irrigation water inputs and related electricity requirements and their subsequent effects on the GWP of wine grapes. The electricity input refers to the $100 \%$ drip irrigation \& average Eskom electricity tariff which is varied according to the energy requirements for the low and high irrigation water amounts.

Results show that the spread between the low irrigation scenario and the high irrigation scenario is $\sim 33 \%$ for the overall GWP and $\sim 72 \%$ for the irrigation contribution to the overall GWP. This highlights the earlier point that the most representative input plays a crucial role in the correctness of the result, which in our case is particularly pronounced for irrigation, as this is not only linked to water resources but also to energy requirements.

\section{Discussion}

To evaluate the robustness and reasonability, our findings were compared to relevant literature. However, direct comparisons were not always possible for a variety of reasons, including differences in LCIA methods (CML baseline 2000), impact categories, unit of measures and functional units of the studies. Further, varying system boundaries, including spatial and temporal system boundaries, imposed limitations. For improved readability, we compare our average results across all analysed options against the literature findings.

Our global warming potential results were dominated by energy usage in vineyards and mainly affected by changes in diesel usage related to farming practices, attributing higher emissions to sustainable farming practices that require more soil management such as tillage, sowing and mowing and were hardly affected by changes in agrochemicals. As highlighted by our sensitivity analysis referring to various irrigation patterns and related electricity requirements, the key to low GHG emissions embedded in wine grapes produced in South Africa lies with the energy requirement for irrigation. Reducing the energy consumption or shifting to a renewable energy source are preferable over other changes in farming practices with regards to the effect on climate change. Our results were comparable to those by van Vuuren (2015) and Ponstein et al. (2019b) who applied the same spatial system boundaries. The former presents an analysis of GHG of Western Cape wine grape production, the latter provides GHG emission data for South African wine grapes in the context of a comprehensive supply chain assessment of wine exported to Finland. van Vuuren (2015) reported an average of $0.42 \mathrm{~kg} \mathrm{CO}_{2}$-eq $/ \mathrm{kg}$ grapes, while Ponstein et al. (2019b) reported an average of $0.30 \mathrm{~kg} \mathrm{CO}$-eq $/ \mathrm{kg}$ grapes produced in South Africa, assuming that $85 \%$ of the domestic vineyards were irrigated. The average result of our study across all the scenarios is $0.46 \mathrm{~kg}$ $\mathrm{CO}_{2}$-eq/kg grape (min: 0.43, max: $0.53 \mathrm{~kg} \mathrm{CO}$-eq/kg grape) which is within the range of previous results for South African wine production, considering a fully irrigated vineyard. In an international comparison, South African wine grapes scored highest due to the high carbon burden of the electricity sector, with France and Germany being at the low end of the scale $\left(0.26 \mathrm{~kg} \mathrm{CO}_{2} \mathrm{e} / \mathrm{kg}\right.$ ) due to a very low level of irrigation (Germany) and a very low carbon burden of electricity (France) (Ponstein et al. 2019b). Since irrigation relies on electricity which translates into indirect emissions from coal-fired power generation in our context, alternative energy sources, such as photovoltaic-powered irrigation as per Wettstein et al. (2017) could be a promising mitigation strategy for South African wine production.

Point et al. (2012), Vázquez-Rowe et al. (2012), Neto et al. (2013), Villanueva-Rey et al. (2014), Meneses et al. (2016) and Vásquez-Rowe et al. (2017a) carried out LCA studies assessing a variety of environmental indicators: acidification potential, eutrophication potential, ozone depletion, photochemical oxidant formation, particulate matter formation, ionizing radiation, agricultural land occupation, freshwater ecotoxicity and human toxicity. Eutrophication potential results from the previous literature listed above range from $3.76 \mathrm{e}-05$ to $3.79 \mathrm{e}-02 \mathrm{~kg}$ P-eq, validating our average result of $3.56 \mathrm{e}-04 \mathrm{~kg}$ P-eq. The previous results on the acidification potential range from $1.07 \mathrm{e}-03$ to $2.23-02 \mathrm{~kg}$ $\mathrm{SO}_{2}$-eq, while we report $3.92 \mathrm{e}-03 \mathrm{SO}_{2}$-eq, which falls within that range.

For the terrestrial, freshwater and human toxicity categories, comparable figures were provided by Point et al. (2012), Neto et al. (2013) and Meneses et al. (2016). For terrestrial toxicity, previous results ranged from 5.04e-04 
to $2.35 \mathrm{e}-03 \mathrm{~kg} 1,4 \mathrm{DCB}$-eq, while our results are $4.89 \mathrm{e}-$ $04 \mathrm{~kg}$ 1,4DBC-eq. For freshwater toxicity, previous literature reports $1.04 \mathrm{e}-02$ to $2.77 \mathrm{e}-02 \mathrm{~kg} 1,4 \mathrm{DCB}$-eq, while we conclude on the significantly higher value of $7.21 \mathrm{e}-02 \mathrm{~kg}$ 1,4DCB-eq. This can be explained by the coal-based electricity production in South Africa as well as the high energy demand for a fully irrigated vineyard. Notably, the Freshwater ecotoxicity was reduced by approximately $30 \%$ when synthetic insecticides were replaced by biological pest control (scenarios 3, 4, 7, 8).

While literature results on human toxicity span from $3.92 \mathrm{e}-02 \mathrm{~kg}$ to $2 \mathrm{e}-01 \mathrm{~kg}$ 1,4DCB-eq, ours, although occurring in the same order of magnitude, are smaller than the lower bound of the said range. Concerning the endpoint category human health, potential damages from wine grape farming ranges from 2.49E-06 to 2.72E-06 DALY(s) per $\mathrm{kg}$ of wine grapes, with the lowest values attributable to the greener farming practices. These numbers translate in years of healthy life lost and could be potentially reduced by greener farming practices. When scaling up the average result to national production (SAWIS, 2018) a potential of 3188 DALY(s) or years of healthy life (on average) would be lost for the whole South African population, which should be expected to primarily affect the most exposed, namely staff working in the vineyards and people living close by.

We find the lack of sensitivity of ReCiPe 2016 towards agrochemicals surprising given the fact that the pesticides are highly toxic to humans, according to the harmonised classification and labelling (CLP) system as issued Annex VI of Regulation (EC) No 1272/2008 (CLP Regulation) (EC 2008). Here, several hazard statement codes are applied to the phytosanitary products replaced in the sustainable viticulture scenarios. For instance, the herbicide Paraquat dichloride is labelled as H330 (fatal if inhaled), H311 (toxic in contact with skin), H301 (toxic if swallowed), H372 (causes damage to organs through prolonged or repeated exposure), and H410 (very toxic to aquatic life with long lasting effects). The insecticide Spirotetramat is classified as H361fd (suspected of damaging fertility and Suspected of damaging the unborn child), amongst others. Yet, there was zero or a very low level of human toxicity arising from agrochemicals reported by ReCiPe 2016 Midpoint and ReCiPe 2016 Endpoint(H) (Fig. 2).

Regarding the endpoint category ecosystems, potential impacts showed neglectable variations across the wine grape farming scenarios with an average value of $1.304 \mathrm{E}-$ 07 species.yr per $\mathrm{kg}$ of wine grapes. That number indicates potential species loss per year and scaling up to the total national wine grape production (SAWIS 2107) an average potential loss of 162 species.yr can be estimated. Verones et al. (2017) highlight the need to understand how resource demand affects ecosystems in order to correctly prioritise policy responses to preserve biodiversity, requirements which were not met by our endpoint category results. Considering that the local ecosystem, renown as the Cape Floral Kingdom, is one of the richest biodiversity hotspots worldwide, the assessment of potential damages to this ecosystem by wine grape farming presented in our study is likely to undervalue the actual potential species loss. Our assumption is supported by the very low sensitivity of the model towards the remarkable reduction in herbicide usage of $70 \%$ and the total avoidance of insecticides in scenarios 4 and 8 (Fig. 4).

Previous studies challenged by the assessment of toxicity in wine grape production added the PestLCI or USEtox (Fantke et al. 2017; Villanueva-Rey et al. 2014, 2019; Vazquez-Rowe et al. 2017b; Hayato et al. 2017). Specifically, Vazquez-Rowe et al. (2017a) extended their initial LCA of Pisco production in Peru with an additional and separate analysis focused on the water and toxicity assessment (Vazquez-Rowe et al. 2017b). The authors applied PestLCI, adapting the dataset to local coastline conditions as well as USEtox and used the AWARE method to estimate water-related impacts (ibid.). Vazquez-Rowe et al. (2017b) conclude that despite the refined PestLCI method, toxicity assessment in LCA is still subject to high uncertainty. Villanueva-Rey et al. (2019) evolved a terrestrial ecotoxicity impact assessment model to suit the local soil conditions in vineyards in Spain and Portugal. The authors found a wide range of impacts attributable to highly variable aspects such as soil types and soil organic carbon, also concluding on a high level of uncertainty inherent to generic characterization factors used in LCA. Based on our findings, we agree with these authors and suggest a follow-up study working on an improved toxicity assessment.

In our water footprint analysis, extended the ReCiPe 2016 method by an impact assessment using a country-based and a watershed-based scarcity indicator which acknowledge the water need of other human activities and the ecosystem (Boulay et al. 2018). The application of the watershed-based indicator displayed that the wine-growing region in the Western Cape is highly prone to water stress, $\sim 19$-fold higher than the global average. The indicator at country level indicates a clearly lower level of water stress which demonstrates that accounting for water scarcity at watershed level is of critical importance to determine the impacts of consumptive water use as stated by FAO (2018). Furthermore, the heavy drought of 2016-2018 and during the year of the analysis, which resulted in extreme water saving measures for agricultural producers and the civil society alike, exemplifies the urgent need for real-time or at least annual data to inform about water scarcity in life cycle assessment. In these years of extreme water scarcity, the actual water stress is underestimated by historical data. Vazquez-Rowe et al. (2017b) also applied the AWARE method and reported regional watershed-based scarcity factors of up to $208.4 \mathrm{~m}^{3} / \mathrm{m}^{3}$ for Pisco production in coastal Peru, one of the most arid regions of the world. 
Given the water stress level of the Perdeberg area, a better management of the water resources could include practices like cover crop in winter season, i.e. growing on rainfall thus not directly affecting abstracted water resources. This coupled with early termination of it by mowing and mulching would increase the infiltration rate and mitigate evaporation in hot summer months which would reduce water volumes required from irrigation.

Benefits of water savings on farms reach beyond water consumption at farm level. A decreased demand for irrigation water translates into lower energy requirements for the pumping equipment and reduced GHG emissions from electricity production. As demonstrated in the sensitivity analysis, the contribution of electricity from irrigation pumps to the GWP of wine grapes can vary between $23 \%$ for low irrigation and $66 \%$ for full irrigation and has a substantial effect on the overall GWP of wine grape production. Given the dominance of electricity inputs for irrigation in most of the impact categories presented in the results section, we suggest that similar effects can be expected for other impact categories. Therefore, in a country heavily relying on coal-fired power, reduced irrigation translates into lower greenhouse gas emission and other adverse environmental and health effects embodied in its agricultural products. Underscoring the annual variability found in wine grape production within the same region (Sinisterra-Solis et al. 2020; Ponstein et al. 2019a; Steenwerth et al. 2015; Vázquez-Rowe et al. 2012), our sensitivity analysis also highlights the importance of applying the most representative input as well as characterization factor for the correctness of the impact assessment results.

\section{Conclusions}

Our model results were dominated by energy requirements of wine grape production of an irrigated vineyard. Strong modifications in the usage of agrochemicals did not lead to corresponding changes in the results concerning the ReCiPe mid-point impact categories terrestrial acidification, freshwater eutrophication, human carcinogenic and non-carcinogenic toxicity as well as the for end-point damage categories human health and ecosystems. In fact, the LCIA results for the BAU scenario were amongst the lowest for these categories. In our impact assessment, the $70 \%$ reduction of toxic agrochemicals such as Glyphosate and Paraquat and the $100 \%$ reduction of the insecticide Chlorpyriphos in vineyards hardly affected the model results for human and ecotoxicity. Our concerns are magnified by the fact that manual labour plays a substantial role in South African vineyards, increasing the exposure of humans to these toxic chemicals at their workplace. Based on our findings, we point towards limitations of generic characterization factors for policy making and scientific relevance. These are particularly expressed for the assessment of water-related impacts due to seasonal and inter-annual variations, human health because of the high exposure of manual labour to agrochemicals, and potential damages to ecosystems due to the toxicity of substances used in wine grape farming and with regard to the unique species richness of the Cape Floral Kingdom. We therefore suggest further research to (a) improve the current toxicity assessment by, e.g. supplementing the ReCiPe method with more granular tools such as PestLCI and USEtox; (b) apply watershed-based characterization factors that reflect the correct level of water scarcity; (c) adjust the assessment of potential impacts on human health to the increased exposure of farm workers in countries with a low degree of mechanization in the agricultural sector. Concluding from this study, a LCA does not replace an occupational risk assessment.

Furthermore, amongst the sustainable farming options, only scenario 7 leads to a lower result for the global warming potential compared to the baseline, related to a slightly lower diesel usage. Concluding, green farming options may have a detrimental effect on global warming when resulting in higher diesel usage and unless increased emissions from this source can be compensated otherwise, e.g. reduced fertiliser applications or a decreased requirement for irrigation. Here, our sensitivity analysis highlights the importance of reducing the electricity requirements related to irrigation or adopting a renewable source of electricity. Given the dominance of environmental impacts from electricity production across all impact categories assessed in our study, sustainably farming options should address the electricity requirements and energy sources in an irrigated vineyard.

Concluding, achieving a more sustainable wine grape production is possible through shifting from current BAU practices to the following:

- Better water and related electricity management through drip irrigation, deficit irrigation and photovoltaicpowered irrigation, which would in turn yield benefits at farm level for future drought-preparedness and less greenhouse gas emissions embodied in products.

- Integrated pest management and winter cover crop practices that strongly reduce the usage of synthetic fertilisers, herbicides and pesticides with effects on the produce itself (less chemicals embodied), reduced ecotoxicity and improved scores on human health.

Since the wine production area is located in a watershed with water stress 19 times higher than the global average, we suggest that future disaster relief programmes include preventive measures such as deficit irrigation, which could also arise from circumstances beyond the farmers' control such as legal water restrictions during droughts. In the light 
of dwindling regional water resources due to high competition for water amongst interest groups and the natural environment, reducing irrigation requirements is of upmost importance in the decades to come.

The recommendations drawn from this study could be relevant for the wine sector and for other agricultural industries in, but not limited to, developing countries which face similar issues, such as high environmental emissions and domestic health risks embodied in their produce, possibly translating into trade barriers.

Acknowledgements We thank Attie Olivier and his viticulture team, Francis Steyn and the Western Cape Department of Agriculture, and those stakeholders in the South African wine industry (farmers, consultants, industry bodies and researchers) who supported this study with data and insights.

Funding Open access funding provided by University of Helsinki including Helsinki University Central Hospital. This work was supported by Deutsches Institut für Nachhaltige Entwicklung (DINE) and the Department for Agriculture, Western Cape Government, South Africa.

Open Access This article is licensed under a Creative Commons Attribution 4.0 International License, which permits use, sharing, adaptation, distribution and reproduction in any medium or format, as long as you give appropriate credit to the original author(s) and the source, provide a link to the Creative Commons licence, and indicate if changes were made. The images or other third party material in this article are included in the article's Creative Commons licence, unless indicated otherwise in a credit line to the material. If material is not included in the article's Creative Commons licence and your intended use is not permitted by statutory regulation or exceeds the permitted use, you will need to obtain permission directly from the copyright holder. To view a copy of this licence, visit http://creativecommons.org/licenses/by/4.0/.

\section{References}

Abrol DP (2013) Integrated pest management: current concepts and ecological perspective. Elsevier Science, Burlington

Amienyo D, Camilleri C, Azapagic A (2014) Environmental impacts of consumption of Australian red wine in the UK. J Clean Prod 72:110-119

Baumgartner K, Steenwerth KL, Veilleux L (2008) Cover crop systems affect weed communities in a California vineyard. Weed Sci 56:596-605

Beauchet S, Rouault A, Thiollet-Scholtus M, Renouf M, Jourjon F, Renaud-Gentié C (2019) Inter-annual variability in the environmental performance of viticulture technical management routesa case study in the Middle Loire Valley (France). Int J Life Cycle Assess 24(2):253-265

Benedetto G (2013) The environmental impact of a Sardinian wine by partial life cycle assessment. Wine Econ Policy 2:33-41

Bitter Grapes-Slavery in the vineyards (2019) [Documentary]. Tom Heinemann, Denmark: Heinemann Media

Björklund AE (2002) Survey of approaches to improve reliability in lca. Int J Life Cycle Ass 7(2):64-72

Bosco S, Di Bene C, Galli M, Remorini D, Massai R, Bonari E (2011) Greenhouse gas emissions in the agricultural phase of wine production in the Maremma rural district in Tuscany, Italy. Ital J Agron 6:e15
Boulay AM, Bare J, Benini L et al (2018) The WULCA consensus characterization model for water scarcity footprints: assessing impacts of water consumption based on available water remaining (AWARE). Int J Life Cycle Ass 23:368-378

Christ KL, Burrit RL (2013) Critical environmental concerns in wine production: an integrative review. J Clean Prod 53:232-242

Dabrowski JM, Shadung JM, Wepener V (2014) Prioritizing agricultural pesticides used in South Africa based on their environmental mobility and potential human health effects. Environ Int 62:31-40. https://doi.org/10.1016/j.envint.2013.10.001

Department of Agriculture, Forestry and Fisheries (DAFF) (2019) Abstract of Agricultural Statistics 2019. Available from http:// www.daff.gov.za/

Ecoinvent (n.d). Available online at https://v36.ecoquery.ecoinvent. org/Search/Index

Eskom (2017) Tariff and Charges Booklet 2016/2017. http://www. eskom.co.za/CustomerCare/TariffsAndCharges/Documents/ 2016_17\%20Tariff\%20Book.pdf

Fairtrade International (no date) Fairtrade Prohibited Materials List. https://www.fairtrade-deutschland.de/fileadmin/DE/01_was_ist_ fairtrade/03_standards/fairtrade_prohibited_materials_list.pdf

FAO (2018) Water use of livestock production systems and supply chains-Guidelines for assessment Livestock Environmental Assessment and Performance (LEAP) Partnership. FAO, Rome, Italy

Ferrara C, De Feo G (2018) Life Cycle Assessment Application to the Wine Sector: A Critical Review. Sustainability 10:395. https://doi. org/10.3390/su10020395

Fourie JC (2010) Soil management in the Breede River Valley wine grape region, South Africa. 1. Cover crop performance and weed control. S Afr J Enol Vitic 31:14-21

Fourie JC, Kunjeku EC, Booyse M, Kutama TG, Sassman LW (2017) Effect of Cover Crops, and the Management Thereof, on the Weed Spectrum in a Drip-irrigated Vineyard: 1. Weeds Growing During Winter and From Grapevine Bud Break to Grapevine Berry Set. S Afr J Enol Vitic 38(2)

Fourie JC, Louw PJE, Agenbag GA (2001) Effect of seeding date on the performance of grasses and broadleaf species evaluated for cover crop management in two wine grape regions of South Africa. S Afr J Plant Soil 18:118-127

Fox R (2000) Bodenpflege und N-Düngung unter Aspekten der Qualitätssicherung. Rebe und Wein 53:202-208

Fantke P (Ed.), Bijster M, Guignard C, Hauschild M, Huijbregts M, Jolliet O, Kounina A, Magaud V, Margni M, McKone TE, Posthuma L, Rosenbaum RK, van de Meent D, van Zelm R (2017) USEtox ${ }^{\circledR}$ 2.0 Documentation (Version 1). http://usetox.org

Frischknecht R, Stucki M (2010) Scope-dependent modelling of electricity supply in life cycle assessments. Int J Life Cycle Ass 15(8):806-816. https://doi.org/10.1007/s11367-010-0200-7

Gallenti G, Troiano S, Marangon F, Bogoni P, Campisi B, Cosmina M (2019) Environmentally sustainable versus aesthetic values motivating millennials' preferences for wine purchasing: evidence from an experimental analysis in Italy. Agric Food Econ 7:12. https://doi.org/10.1186/s40100-019-0132-X

Gazulla C, Raugei M, Fullana-i-Palmer P (2010) Taking a life cycle look at Crianza wine production in Spain: where are the bottlenecks? Int J Life Cycle Ass 15:330-337

Harding KG, Friedrich E, Jordaan H, le Roux B, Notten P, Russo V, Suppen-Reynaga N, van der Laan M Goga T (2020) Status and prospects of life-cycle studies in South Africa (2011 - 2019). Int J Life Cycle Ass. https://doi.org/10.1007/s11367-020-01839-0

Hastings T (2019) Leveraging Nordic links: South African labour's role in regulating labour standards in wine global production networks. J Econ Geogr 19(4):921-942. https://doi.org/10.1093/jeg/lbz010

Hayato SA, Tiruta-Barna L, Ahmadi A (2017) Operational Integration of time dependent toxicity impact category in dynamic LCA. Sci Total Environ 599-600:806-819 
Huijbregts M, Steinmann Z, Elshout P, Stam G, Verones F, Vieira M, Hollander A, Van Zelm R (2016) ReCiPe2016: A harmonized life cycle impact assessment method at midpoint and endpoint level. RIVM Report 2016-0104. Bilthoven, The Netherlands: National Institute for Public Health and the Environment

Jradi S, Chameeva TB, Delhomme B, Jaegler A (2018) Tracking carbon footprint in French vineyards: A DEA performance assessment. J Clean Prod 192:43-54

Lamastra L, Balderacchi M, Di Guardo A, Monchiero M, Trevisan M (2016) A novel fuzzy expert system to assess the sustainability of the viticulture at the wine-estate scale. Sci Total Environ 572:724-733

Marras S, Masia S, Duce P, Spano D, Sirca C (2015) Carbon footprint assessment on a mature vineyard. Agric For Meteorol 214-215:350-356

Meneses M, Torres CM, Castells F (2016) Sensitivity analysis in a life cycle assessment of an aged red wine production from Catalonia, Spain. Sci Total Environ 562:571-579. https://doi.org/10.1016/j. scitotenv.2016.04.083

Nemecek T, Schnetzer J (2011) Methods of Assessment of Direct Field Emission for LCIs of Agricultural Production Systems, Zürich

Neto B, Días AC, Machado M (2013) Life cycle assessment of the supply chain of a Portuguese wine: from viticulture to distribution. Int J Life Cycle Ass 18:590-602. https://doi.org/10.1007/ s11367-012-0518-4

OIV (2019) Statistical Report of World Vitiviniculture, International Organisation of Vine and Wine Intergoveramental Organisation. Available on-line at http://www.oiv.int/public/medias/6782/oiv2019-statistical-report-on-world-vitiviniculture.pdf

Peters GP, Hertwich EG (2007) Policy analysis CO 2 embodied in international trade with implications for global climate policy. https://doi.org/10.1021/es072023k

Peth D, Drastig K, Prochnow A (2017) Quantity- and quality-based farm water productivity in wine production: case studies in Germany. Water 9(2):88

Pineo C (2015) Regional resource flow model : Grain Sector Report

Point E, Tyedmers P, Naugler C (2012) Life Cycle environmental impacts of wine production and consumption in Nova Scotia, Canada. J Clean Prod 27:11-20. https://doi.org/10.1016/j.jclepro. 2011.12.035

Ponstein HJ, Ghinoi S, Steiner B (2019a) How to increase sustainability in the Finnish wine supply chain? J. Clean Prod, Insights from a country of origin based greenhouse gas emissions analysis. https:// doi.org/10.1016/j.jclepro.2019.04.088

Ponstein HJ, Meyer-Aurich A, Prochnow A (2019b) Greenhouse gas emissions and mitigation options for German wine production. J Clean Prod 212:800-809. https://doi.org/10.1016/j.jclepro.2018. 11.206

Ramanathan U, Bentley Y, Pang G (2014) The role of collaboration in the UK green supply chains: an exploratory study of the perspectives of suppliers, logistics and retailers. J Clean Prod 70:231-241. https://doi.org/10.1016/J.JCLEPRO.2014.02.026

Regulation (EC) (2008) No 1272/2008 of the European Parliament and of the Council of 16 December 2008 on classification, labelling and packaging of substances and mixtures, amending and repealing Directives 67/548/EEC and 1999/45/EC, and amending Regulation (EC) No 1907/2006 (Text with EEA relevance). Current consolidated version: 01/01/2020 (Online). https://eur-lex. europa.eu/legal-content/EN/TXT/PDF/?uri=CELEX:32008 $\mathrm{R} 1272 \&$ from $=\mathrm{EN}$
Rugani B, Vázquez-Rowe I, Benedetto G, Benetto E (2013) A comprehensive review of carbon footprint analysis as an extended environmental indicator in the wine sector. J Clean Prod 54:61-77

SAWIS (2018) SA Wine Industry 2018 Statistics. www.sawis.co.za

Sinisterra-Solís NK, Sanjuán N, Estruch V, Clemente G (2020) Assessing the environmental impact of Spanish vineyards in UtielRequena PDO: the influence of farm management and on-field emission modelling. J Environ Manage 262:110325

South Africa Weather Service (no date). Available online at http:// www.weathersa.co.za/climate/historical-rain-maps

Steenwerth KL, Strong EB, Greenhut RF, Williams L, Kendall A (2015) Life cycle greenhouse gas, energy and water assessment of wine grape production in California. Int J Life Cycle Ass 20:1243-1253. https://doi.org/10.1007/s11367-015-0935-2

Swanton CJ, Weise SF (1991) Integrated weed management: the rationale and approach. Weed Technol 5(3):657-663

van Vuuren PFJ (2015) Regional Resource Flow Model Wine Sector, RRFM 2014/15: Wine Grape Sector Report, Greencape

Vázquez-Rowe I, Cárceres AL, Torres-García JR, Quispe I, Kahhat R (2017a) Life cycle assessment of the production of Pisco in Peru. J Clean Prod 142:4369-4383. https://doi.org/10.1016/j.jclepro. 2016.11.136

Vázquez-Rowe I, Rugani B, Benetto E (2013) Tapping carbon footprint variations in the European wine sector. J Clean Prod 43:146-155

Vázquez-Rowe I, Torres-García JR, Cárceres AL, Larrea-Gallegos G, Quispe I, Kahhat R (2017b) Assessing the magnitude of potential environmental impacts related to water and toxicity in Peruvia hyper-arid coast: A case study for the cultivation of grape of pisco production. Science of Total Environment 601-602:532-542. https://doi.org/10.1016/j.sctitotenv.201705.221

Vázquez-Rowe I, Villanueva-Rey P, Moreira MT, Feijoo G (2012) Environmental analysis of Ribeiro wine from a timeline perspective: harvest year matters when reporting environmental impacts. J Environ Manage 98:73-83. https://doi.org/10.1016/j.jenvman. 2011.12.009

Verones F, Moran D, Stadler K et al (2017) Resource footprints and their ecosystem consequences. Sci Rep 7:40743. https://doi.org/ 10.1038/srep40743

Villanueva-Rey P, Vásquez-Rowe I, Moreira MT, Feijoo G (2014) Comparative Life cycle assessment in the wine sector: biodynamic vs. conventional viticulture activities in NW Spain. J Clean Prod 65:330-341. https://doi.org/10.1016/j.jclepro.2013.08.026

Villanueva-Rey P, Vázquez-Rowe I, Quinteiro P, Rafael S, Gonçalves C, Moreira MT, Feijoo G, Arroja L, Dias AC, A. C., (2019) Regionalizing eco-toxicity characterization factors for copper soil emissions considering edaphic information for Northern Spain and Portuguese vineyards. Sci Total Environ 686:986-994

Vink N, Deloire A, Bonnardot V, Ewert J (2012) Climate change and the future of South Africa's wine industry. Int J Clim Chang Str 4(4):420-441. https://doi.org/10.1108/17568691211277746

Wettstein S, Muir K, Scharfy D, Stucki M (2017) The environmental mitigation potential of photovoltaic-powered irrigation in the production of South African Maize. Sustainability 9(10):1772. https://doi.org/10.3390/su9101772

WIETA (2019) WIETA Code (Online). http://wieta.org.za/wieta-code/. Accessed 10.12.2020

Publisher's Note Springer Nature remains neutral with regard to jurisdictional claims in published maps and institutional affiliations. 